\title{
Trophic ecology of nematodes from various microhabitats of the Roscoff Aber Bay (France): importance of stranded macroalgae evidenced through $\delta^{13} \mathrm{C}$ and $\delta^{15} \mathrm{~N}$
}

\author{
P. Riera* ${ }^{*}$ C. Hubas \\ Station Biologique de Roscoff, Université Pierre \& Marie Curie Paris VI - CNRS-INSUE, Place Georges-Teissier, BP 74, \\ 29682 Roscoff cedex, France
}

\begin{abstract}
Spatial and temporal diversity of food sources of intertidal nematodes of 3 different feeding habitats (estuarine muddy sediments, Spartina maritima and Juncus maritimus marshes) in the Roscoff Aber Bay, France, was assessed by the use of $\delta^{13} \mathrm{C}$ and $\delta^{15} \mathrm{~N}$ values. Within the bay, nematodes largely dominated within the total meiofauna. Throughout the 3 sampling periods, the $\delta^{13} \mathrm{C}$ and $\delta^{15} \mathrm{~N}$ values for nematodes and sources showed that the dominant sedimentary organic matter sources within the 3 microhabitats considered, namely terrigeneous inputs, detrital Spartina maritima or Juncus maritimus and marine POM, did not contribute a significant part of the diet to locally occurring nematodes. In fact, the $\delta^{13} \mathrm{C}$ and $\delta^{15} \mathrm{~N}$ values indicate that organic matter derived from stranded macroalgae, mostly Enteromorpha sp. and Fucus spiralis, was the primary contributor to the assimilated food sources of nematodes; more readily utilisable sources (i.e. benthic diatoms) are virtually absent. The present work provides evidence that detrital pathways, including stranded macroalgae from nearby rocks and free-living nematodes, play a key role in the trophic ecology of intertidal flat areas.
\end{abstract}

KEY WORDS: Nematodes $\cdot$ Feeding ecology $\cdot$ Intertidal bay $\cdot$ Stranded algae $\cdot$ Stable isotopes

\section{INTRODUCTION}

Intertidal environments are generally characterised by a high diversity of locally produced and allochthonous food sources available to benthic consumers. Within intertidal areas a key role in the transfer of organic matter is assigned to meiofauna, due to its abundance and its intermediary trophic position between the primary producers and the top predators (Coull \& Bell 1979). In particular, the quantitative importance of free-living nematodes in sediments with a high organic matter content was noted by Bongers \& Ferris (1999). Meiobenthic fauna consist mainly of grazers adapted to the ingestion of specific microbial food items such as bacteria and microalgae (Gerlach 1978, Colijn \& de Jonge 1984, Moens \& Vincx 1997).
Previous experimental and field studies on feeding have revealed the complexity of feeding strategies of meiobenthos subjected to diverse ecological conditions (Montagna \& Yoon 1991, Montagna 1995). For example, in the mudflats of Marennes-Oléron Bay, France, where vascular plants such as Spartina are virtually absent, benthic diatoms represented the main foodsource ingested (Montagna et al. 1995) and assimilated by nematodes over a sampling year (Riera et al. 1996). In contrast, in the salt marsh of Aiguillon Bay, France, stable isotope studies of nematodes suggested a higher diversity of food sources, including benthic diatoms and detritus derived from other sources (Riera et al. 1999). This was consistent with the suggestion of Couch (1989) that microphytobenthos does not constitute the sole food source of nematodes, and that detri- 
tus derived from marine phanerogams can be an important food source for meiofauna.

Although the diversity of food sources for meiofauna has long been recognised, the trophic pathways in which free-living nematodes are involved still remain incompletely understood. In particular, in coastal ecosystems a significant fraction of the macroalgal biomass is generally deposited ashore after being dislodged by currents and waves (Branch \& Griffiths 1988). Macroalgae can enter the coastal food web through different pathways, mostly related to detritic food chains (Pomeroy 1980, Adin \& Riera 2003). For example, on a sandy beach of the west coast of the Cape Peninsula, South Africa, Griffiths et al. (1983) reported that $53 \%$ of the annual seaweed deposition was consumed by talitrid amphipods. Hence, in addition to locally produced marine plants and microphytobenthos, the stranded macroalgae may represent a primary food source for meiofauna inhabiting intertidal sediments. Analysis of carbon and nitrogen stable isotope ratios has recently received increasing interest in the study of coastal environments because it allows the determination of exchanges which occur

Fig. 1. Location of the sampling station in the Roscoff Aber Bay (France)
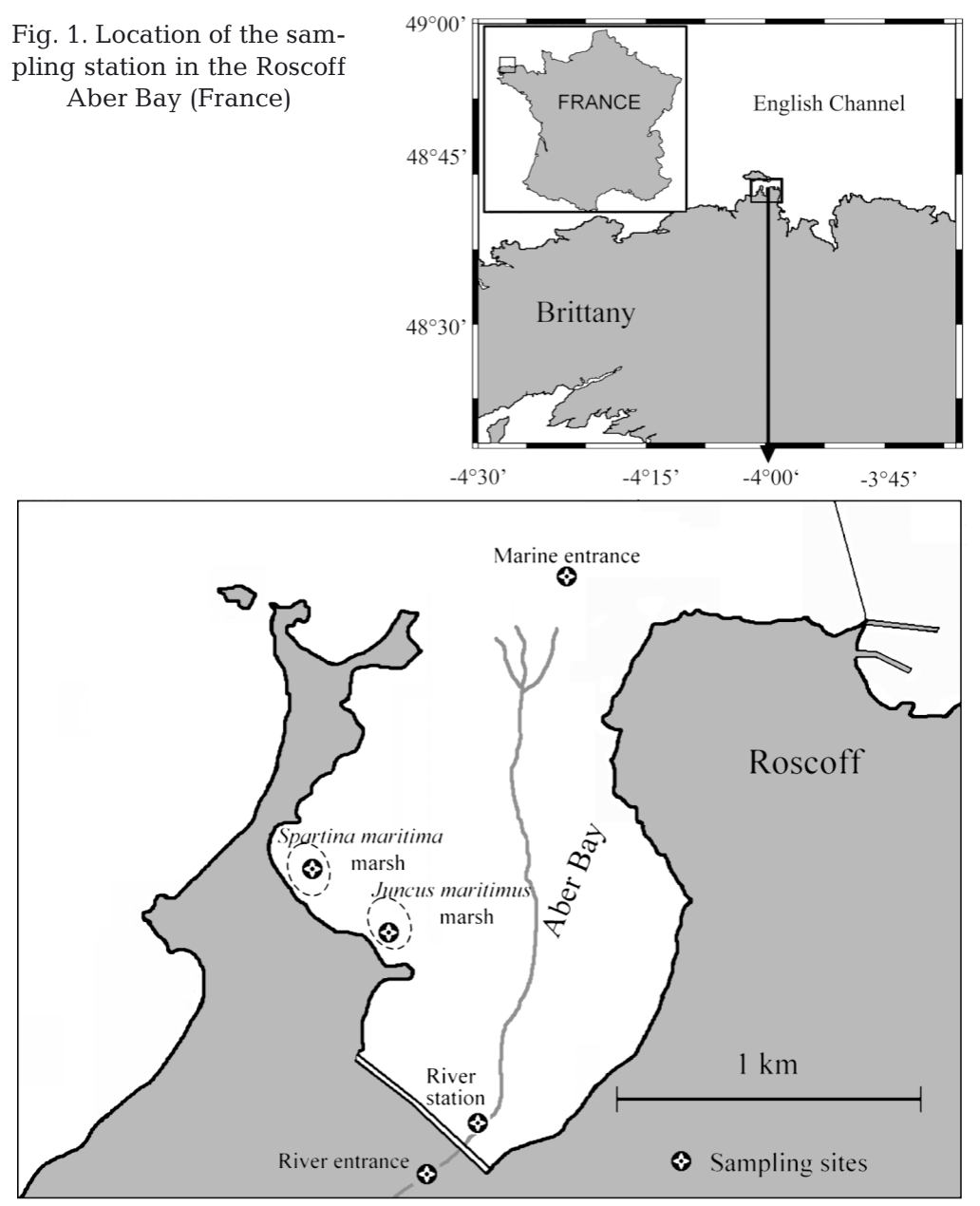

between different sources of organic matter and marine fauna during trophic interactions (Fry \& Sherr 1984, Deegan et al. 1990). However, in contrast to macrofauna, smaller organisms such as meiofauna have been subject to very few stable isotope studies due to low biomass and methodological constraints of performing accurate analyses (Couch 1988, Riera et al. 1996, Carman \& Fry 2002, Moens et al. 2002).

The aim of the present study was to assess the spatial and temporal diversity of food sources of intertidal nematodes from various feeding habitats differing in their dominant organic matter sources, using $\delta^{13} \mathrm{C}$ and $\delta^{15} \mathrm{~N}$.

\section{MATERIALS AND METHODS}

The Roscoff Aber Bay is ca. $2 \mathrm{~km}$ long and $1 \mathrm{~km}$ wide, and includes different types of intertidal sediments (Rullier 1959). The bay is very shallow (average depth $4 \mathrm{~m})$, located completely above mid-tide level, has strong currents, and a tidal range of ca. $4 \mathrm{~m}$ that leads to generally good mixing and high turbidity (Chauris 1988). The southern end of Aber Bay is limited by a dike, which contains a sluice gate that allows river input into the bay (Fig. 1). In this bay, 3 sampling stations corresponding to 3 habitat types for nematodes were considered. The 'river station' located at the river entrance into the bay consists of estuarine sandy, muddy sediments. Two other stations are located in the southern part of the bay where the sandy, muddy sediment is colonised by 2 small marshes from ca. 40 to $50 \mathrm{~m}$ in length and width, namely Spartina maritima and Juncus maritimus marshes (Fig. 1).

Meiofauna abundance. In order to assess the quantitative importance of nematodes within the total meiofauna, 2 sampling periods were selected, in January and March 2002. On each sampling occasion, a set of sediment cores was collected using a sampler made of 9 cut-off plastic syringes (14 mm inner diameter) arranged regularly within an area of $1 \mathrm{~m}^{2}(100 \times 100 \mathrm{~cm})$. For each syringe, the top $2 \mathrm{~cm}$ of sediment was retained (Coull \& Bell 1979), which corresponded to a volume of $3 \mathrm{~cm}^{3}$. The sediment was fixed in $5 \%$ formalin and stained with Rose Bengal. Counting of meiofauna and identification to major meiofauna taxa was performed within a Dolphus cuve using a magnifying glass and microscope.

Collection and sample preparation. At the marine entrance of the Aber Bay 
(Fig. 1), POM (suspended particulate organic matter) was sampled by collecting 21 bottles of water at high tide $( \pm 1 \mathrm{~h})$ from a depth of ca. $50 \mathrm{~cm}$ below the water's surface. To characterise POM from the river, 21 bottles of freshwater were collected at low tide at the 'river entrance' in the bay (Fig. 1). POM for isotope analysis was collected by filtration on precombusted Whatman GF/F glass fiber filters within $1 \mathrm{~h}$ of collection. Subsequently, the filters were acidified $(1 \mathrm{M} \mathrm{HCl})$ in order to remove carbonates, rinsed with distilled water, dried $\left(60^{\circ} \mathrm{C}\right.$, $24 \mathrm{~h})$, and kept frozen $\left(-32^{\circ} \mathrm{C}\right)$ until analysis. At low tide, muddy, sandy sediment samples were taken at the river station by scraping the upper $1 \mathrm{~cm}$ of sediment. For the measurements of stable isotopic ratios of the sedimented organic matter (SOM), the sand was sieved to a grain size of $<63 \mu \mathrm{m}$ to separate sand grains from most of the sedimentary particulate organic matter. The SOM fraction $<63 \mu \mathrm{m}$ was acidified in a glass receptacle with $1 \mathrm{M} \mathrm{HCl}$, rinsed several times with distilled water, dried $\left(60^{\circ} \mathrm{C}\right)$ and ground to powder using a mortar and pestle. At low tide, live and dead leaves and twigs of Spartina maritima and Juncus maritimus were collected by hand. These samples were cleaned of their epibionts, washed with $1 \mathrm{M} \mathrm{HCl}$ to remove carbonates, and rinsed with distilled water. Subsequently, the samples were dried $\left(60^{\circ} \mathrm{C}\right)$ and ground to powder using a mortar and pestle. During summer, benthic diatoms were collected at low tide at the river station by scraping the surface of the sediment and extracting them according to the method of Couch (1989), slightly modified by Riera \& Richard (1996).

For stable isotope analyses, on each sampling occasion nematodes were collected at low tide by scraping the upper $2 \mathrm{~cm}$ of sediments, where most of the meiofauna are present (Coull \& Bell 1979), and extracting them along with ca. 21 of sediment; they were later removed from sediment in the laboratory. Meiofauna was cautiously sieved from the sediment through a $500 \mu \mathrm{m}$ sieve, and subsequently through a $125 \mu \mathrm{m}$ sieve, where they were retained along with large particles, and the sample volume was decreased (Couch 1988). The fraction retained on the $125 \mu \mathrm{m}$ sieve was used for the extraction of nematodes. Nematodes were handpicked using a fine needle from the concentrated sediment within a Dolphus cuve, which allowed the live collection of all individuals without chemical contaminants. Following extraction, the nematodes were starved $(12 \mathrm{~h}$ in $0.7 \mu \mathrm{m}$ filtered seawater), during which time the gut contents were cleared. Nematodes were then rinsed and remaining debris was manually removed, using a dissecting microscope. Nematodes were finally collected on precombusted Whatman GF/F glass fiber filters (80 to 100 pooled individuals per filter), briefly rinsed with distilled water, and dried $\left(60^{\circ} \mathrm{C}, 24 \mathrm{~h}\right)$. All samples were kept frozen $\left(-32^{\circ} \mathrm{C}\right)$ until analysis.
Isotope analysis. Carbon and nitrogen isotope ratios were determined using a CHN analyser (ThermoFinnigan 1112 Series) interfaced with a mass spectrometer (ThermoFinnigan MAT Delta ${ }^{\text {plus }}$ ) via a Conflow III open split interface. Data are expressed in standard $\delta$ unit notation, where $\delta \mathrm{X}=\left[\left(R_{\text {sample }} / R_{\text {reference }}\right)-1\right] \times 10^{3}$, where $R$ is either the ${ }^{13} \mathrm{C}:{ }^{12} \mathrm{C}$ ratio for carbon or the ${ }^{15} \mathrm{~N}:{ }^{14} \mathrm{~N}$ ratio for nitrogen. These values are reported relative to the Vienna Pee Dee Belemnite standard (PDB) for carbon and to air $\mathrm{N}_{2}$ for nitrogen. A laboratory working standard (Peptone) was run for every 10 samples. Average reproducibilities based on replicate measurements, using the Peptone standard, for $\delta^{13} \mathrm{C}$ and $\delta^{15} \mathrm{~N}$ were less than $\pm 0.10 \%$.

\section{RESULTS}

\section{Meiofauna taxon abundances}

The relative densities in the taxonomic composition of meiofauna differed slightly among the 3 sampling stations (Fig. 2). On each sampling occasion, Nematoda was the dominant taxonomic group because it represented at least $50 \%$ of the total meiofaunal abundance, as already observed in similar sediments (Blanchard 1990). The co-occurring main taxonomic groups included harpacticoid copepods, ostracods, and oligochaetes, which were much less abundant. Nematodes have regularly been observed as the predominant taxonomic group of the meiofauna in the Roscoff Aber Bay since 1998 (Riera unpubl. data). The numerical importance of nematodes may confer on this group a key role in the trophic ecology of the bay. Also, high standard deviations are observed for the mean densities of the different taxonomic groups (Fig. 2), which typically suggests a patchy distribution of meiobenthos, and is consistent with previous microscale dispersion studies of meiofauna in intertidal sediments (Blanchard 1990).

\section{$\delta^{13} \mathrm{C}$ and $\delta^{15} \mathrm{~N}$ of organic matter sources and nematodes}

$\delta^{13} \mathrm{C}$ and $\delta^{15} \mathrm{~N}$ (range of values) of POM, SOM, food sources and nematodes are presented in Table 1. Average $\delta^{13} \mathrm{C}$ values for living and detrital Spartina maritima and Juncus maritimus clearly reflected the C4 and C3 pathways of photosynthesis, respectively (Fry \& Sherr 1984). Both detrital marine phanerogams exhibited lower $\delta^{13} \mathrm{C}$ as compared to the corresponding living plant. The bacterial degradation of angiosperms such as Spartina may change the $\delta^{13} \mathrm{C}$ value, depending on the environmental conditions and the duration of the processes (Currin et al. 1995). Since this plant has a high 
content of lignin, which is very ${ }^{13} \mathrm{C}$-depleted (Benner et al. 1987), the observed depletion of the $\delta^{13} \mathrm{C}$ associated with the non-aerial degradation of Spartina has been ascribed to the conservation of this refractory component over a long period of time (Currin et al. 1995). Also, a large difference in $\delta^{15} \mathrm{~N}$ was observed between live and dead J. maritimus. Previous studies reported that $\delta^{15} \mathrm{~N}$ variation observed for detritus from marine plants (i.e. S. alterniflora) resulted largely from the uptake of external nitrogen by bacteria associated with plant detritus, as well as from adsorbed external nitrogenous compounds
(Rice 1982, Couch 1989, Whites \& Howes 1994). In the present study, these differences were less pronounced between live and dead Spartina maritima. The $\delta^{13} \mathrm{C}$ for benthic diatoms was close to the $\delta^{13} \mathrm{C}$ reported for benthic diatoms in mudflats of Marennes-Oléron Bay (Riera et al. 1996), while the corresponding $\delta^{15} \mathrm{~N}$ was comparable to that $(9.1 \pm 0.2 \%$ o) observed in muddysandy sediments of the middle Oosterschelde, The Netherlands (Riera et al. 2000).

At each sampling station, the food sources and the nematodes exhibited temporal $\delta^{13} \mathrm{C}$ variation (Table 1).

\section{A. River Station}

January 2002

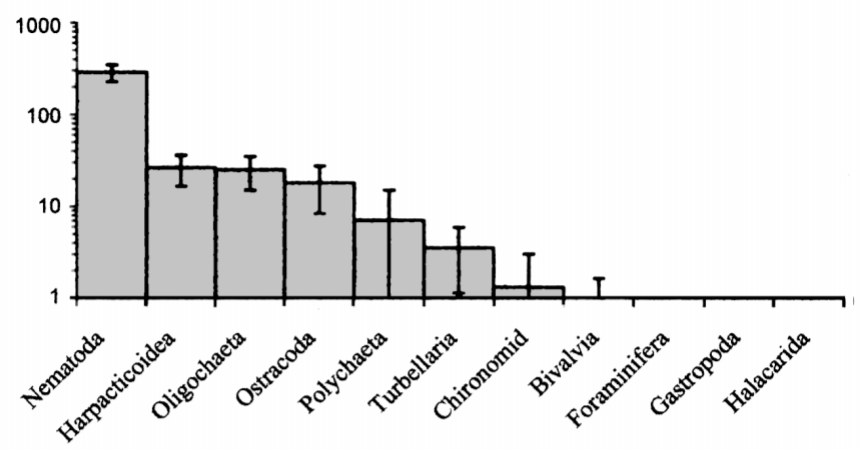

March 2002

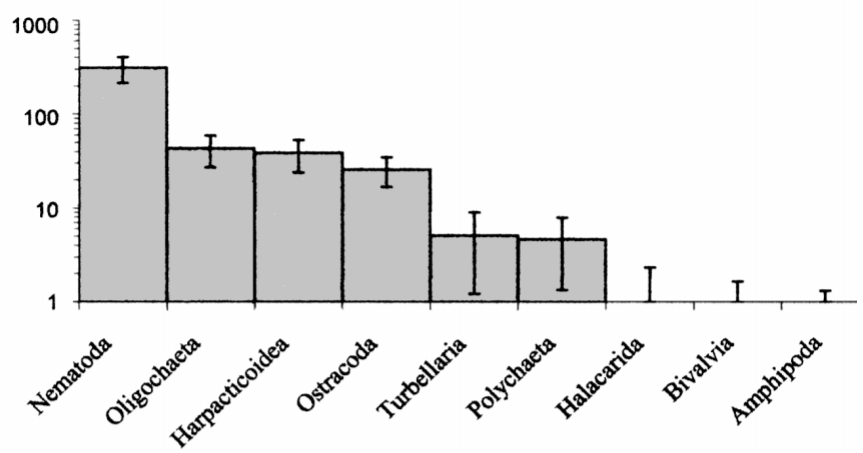

\section{B. Juncus maritimus marsh}
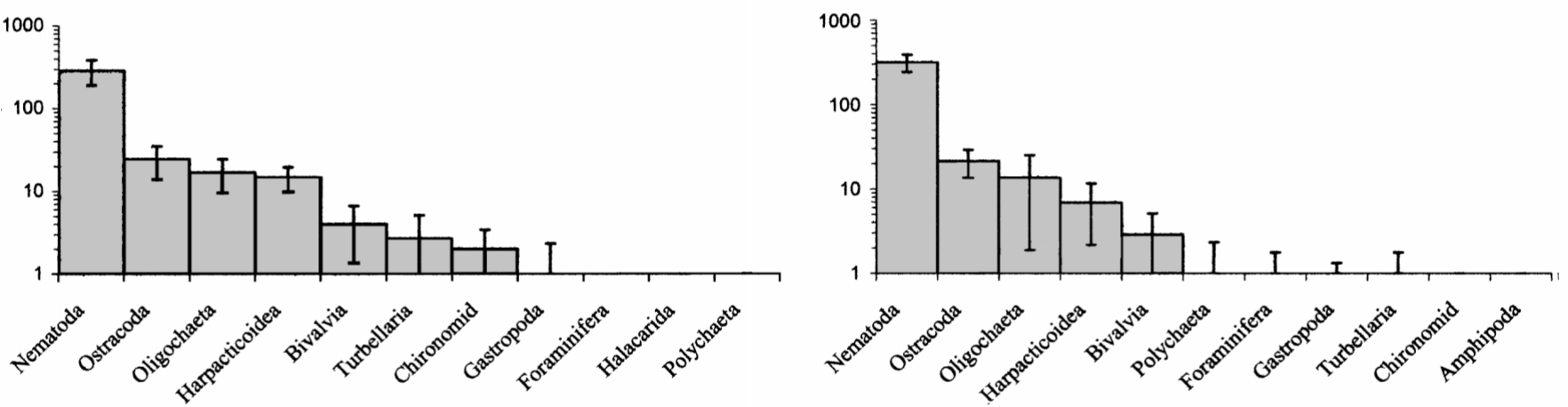

\section{Spartina maritima marsh}
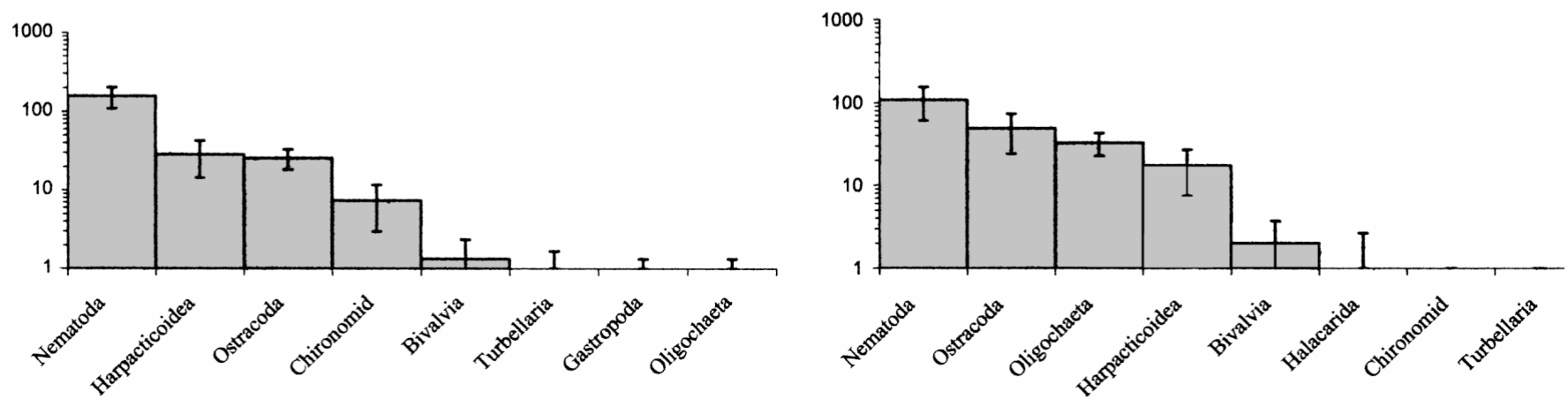

Fig. 2. Number of individuals per $3 \mathrm{~cm}^{3}$ surficial sediment for the main taxonomic groups of meiofauna in different microhabitats during January 2001 and March 2002. (A) River station, (B) Juncus maritimus marsh, (C) Spartina maritima marsh. Error bars: \pm 1 SD 
Table 1. Comparison of $\delta^{13} \mathrm{C}$ and $\delta^{15} \mathrm{~N}$ (range values) of the organic matter sources and nematodes (n: pooled 80 to 100 individuals) of the intertidal Aber Bay at (a) the river station and (b) the Spartina maritima and the Juncus maritimus marshes during January, March and August 2002. 2- and 3-date comparisons were performed by Mann-Whitney $U$-test and Kruskal-Wallis test, respectively. n: number of samples. -: not sampled. SOM: sedimented organic matter; POM: particulate organic matter

\begin{tabular}{|c|c|c|c|c|c|c|c|c|c|c|c|}
\hline & \multicolumn{2}{|c|}{ January 2002} & \multirow[b]{2}{*}{$\mathrm{n}$} & \multicolumn{2}{|c|}{ March 2002} & \multicolumn{3}{|c|}{ August 2002} & \multirow[b]{2}{*}{$\mathrm{n}$} & \multicolumn{2}{|c|}{ p-value (date) } \\
\hline & $\delta^{13} \mathrm{C}$ & $\delta^{15} \mathrm{~N}$ & & $\delta^{13} \mathrm{C}$ & $\delta^{15} \mathrm{~N}$ & $\mathrm{n}$ & $\delta^{13} \mathrm{C}$ & $\delta^{15} \mathrm{~N}$ & & $\delta^{13} \mathrm{C}$ & $\delta^{15} \mathrm{~N}^{\prime}$ \\
\hline \multicolumn{12}{|l|}{ (a) River mouth } \\
\hline SOM & -26.8 to -22.9 & 4.6 to 5.6 & 3 & -19.5 to -19.3 & 6.3 to 7.5 & 3 & -15.5 to -15.2 & 7.6 to 7.7 & 2 & 0.04 & 0.04 \\
\hline Marine POM & -25.5 to -23.3 & 3.2 to 4.3 & 3 & -19.5 to -19.3 & 4.6 to 5.2 & 3 & -18.0 to -17.4 & 4.7 to 5.5 & 2 & 0.04 & 0.07 \\
\hline River POM & -31.8 to -30.0 & 7.6 to 8.9 & 3 & -30.2 to -29.7 & 7.8 to 9.3 & 3 & -26.0 to -25.7 & 7.0 to 7.0 & 2 & 0.07 & 0.10 \\
\hline Fucus spiralis & -24.5 to -23.3 & 8.1 to 8.7 & 3 & -19.3 to -19.0 & 6.2 to 6.5 & 3 & -15.3 to -14.1 & 3.8 to 5.9 & 2 & 0.04 & 0.02 \\
\hline Enteromorpha sp. & -21.7 to -18.6 & 8.6 to 9.3 & 3 & -11.6 to -10.2 & 9.1 to 9.5 & 3 & -16.8 to -16.4 & 5.7 to 7.2 & 3 & 0.02 & 0.054 \\
\hline Benthic diatoms & - & - & & - & - & & -17.3 to -16.9 & 8.3 to 9.1 & 3 & & \\
\hline Nematodes & -24.3 to -19.1 & 11.3 to 14.3 & 6 & -19.5 to -16.0 & 9.0 to 13.4 & 5 & -17.0 to -16.3 & 11.4 to 13.4 & 4 & 0.01 & 0.40 \\
\hline \multicolumn{12}{|c|}{ (b) Spartina/Juncus marshes } \\
\hline $\begin{array}{l}\text { SOM Juncus } \\
\text { maritimus clump }\end{array}$ & -29.0 to -23.9 & 2.3 to 4.1 & 2 & - & - & & - & - & & & \\
\hline Marine POM & -25.5 to -23.3 & 3.2 to 4.3 & 3 & -19.5 to -19.3 & 4.6 to 5.2 & 3 & -18.0 to -17.4 & 4.7 to 5.5 & 2 & 0.04 & 0.07 \\
\hline $\begin{array}{l}\text { Living Spartina } \\
\text { maritima }\end{array}$ & -19.0 to -17.6 & 4.1 to 4.2 & 4 & -15.1 to -14.8 & 3.8 to 4.2 & 3 & - & - & & & \\
\hline $\begin{array}{l}\text { Detrital Spartina } \\
\text { maritima }\end{array}$ & -21.0 to -20.2 & 3.3 to 4.1 & 3 & -12.9 to -12.7 & 3.2 to 4.4 & 3 & - & - & & & \\
\hline $\begin{array}{l}\text { Living Juncus } \\
\text { maritimus }\end{array}$ & -30.2 to -29.5 & 9.1 to 9.4 & 3 & -24.8 to -24.4 & 4.0 to 4.9 & 3 & - & - & & & \\
\hline $\begin{array}{l}\text { Detrital Juncus } \\
\text { maritimus }\end{array}$ & -31.5 to -30.7 & 2.7 to 3.8 & 3 & -26.1 to -25.7 & 0.8 to 1.7 & 3 & -25.9 to -25.1 & 4.4 to 6.6 & 2 & 0.02 & 0.46 \\
\hline Fucus spiralis & -21.5 to -19.9 & 7.1 to 7.4 & 3 & -18.1 to -17.9 & 4.5 to 5.9 & 3 & -16.5 to -16.5 & 3.3 to 4.2 & 3 & 0.02 & 0.02 \\
\hline Enteromorpha sp. & -22.9 to -20.7 & 7.3 to 7.4 & 3 & -11.7 to -11.4 & 7.8 to 9.2 & 3 & -17.0 to -16.7 & 6.7 to 7.2 & 3 & 0.02 & 0.02 \\
\hline $\begin{array}{l}\text { Nematodes } \\
\text { (Spartina marsh) }\end{array}$ & -23.9 to -17.8 & 9.0 to 13.2 & 6 & -16.6 to -15.4 & 10.9 to 12.5 & 5 & - & - & & 0.009 & 0.75 \\
\hline $\begin{array}{l}\text { Nematodes } \\
\text { (Juncus maritimu }\end{array}$ & $\begin{array}{l}-27.0 \text { to }-20.3 \\
s \text { marsh) }\end{array}$ & 9.1 to 12.1 & 6 & -18.4 to -16.4 & 6.1 to 10.4 & 5 & -16.1 to -14.8 & 9.5 to 11.2 & 4 & 0.003 & 0.04 \\
\hline
\end{tabular}

In contrast, there were no consistent differences of $\delta^{15} \mathrm{~N}$ values among sampling dates for the food sources and nematodes. In addition to temporal differences, there can be isotopic across-site differences for the food sources and nematodes. During each sampling date, there were no $\delta^{13} \mathrm{C}$ differences between sampling areas for Enteromorpha sp. (Mann-Whitney $U$-test, $\mathrm{p}=0.27,0.19$ and 0.51 in January, March and August, respectively), while stranded Fucus spiralis showed more consistent $\delta^{13} \mathrm{C}$ across-site differences (MannWhitney $U$-test, $\mathrm{p}<0.05$ in January and March, and $\mathrm{p}=0.08$ in August). Corresponding across-site comparisons for $\delta^{15} \mathrm{~N}$ were observed in January for Enteromorpha sp. and F. spiralis (Mann-Whitney U-test, $\mathrm{p}<0.05)$ and for F. spiralis in March $(\mathrm{p}<0.05)$, whereas there was no significant difference for stranded Enteromorpha sp. in March, or for either macroalgae in August (Mann-Whitney $U$-test, p > 0.2). During January and March, no significant differences in the $\delta^{13} \mathrm{C}$ values among stations were observed for nematodes (Kruskal-Wallis test, $\mathrm{p}>005)$, while the corresponding $\delta^{15} \mathrm{~N}$ values were different $(\mathrm{p}<0.05$ in January and March). In August, $\delta^{13} \mathrm{C}$ and $\delta^{15} \mathrm{~N}$ differences for nematodes among habitats were observed (Table 1), suggesting differences in food sources.

\section{DISCUSSION}

\section{Determination of the main nutritional sources for nematodes}

The main sources of organic matter had reasonably distinct $\delta^{13} \mathrm{C}$ vs. $\delta^{15} \mathrm{~N}$ values, which enabled us to infer the food sources utilised by nematodes (Fig. 3). In particular, the high $\delta^{13} \mathrm{C}$ difference between Juncus maritimus and Spartina maritima gave the opportunity to infer the contribution of the 2 marine plants to the diet of the locally occurring nematodes.

The mean isotopic composition of the diet of nematodes can be estimated by considering a mean trophic enrichment in $\delta^{13} \mathrm{C}$ of $1 \%$ o (DeNiro \& Epstein 1978, Rau et al. 1983) and a mean trophic enrichment in $\delta^{15} \mathrm{~N}$ of 3.4\% (DeNiro \& Epstein 1981, Minagawa \& Wada 1984, Post 2002) as a result of the assimilation of food. For each sampling occasion, the trophic enrichments in ${ }^{13} \mathrm{C}$ and ${ }^{15} \mathrm{~N}$ are shown in Fig. 3 (dashed line), starting from the mean $\delta^{13} \mathrm{C}$ vs. $\delta^{15} \mathrm{~N}$ of nematodes. The closer the theoretical $\delta^{13} \mathrm{C}$ vs. $\delta^{15} \mathrm{~N}$ value of a consumer's food is to the one of a pure food source, the higher the proportion of that source in the diet of the consumer must be, as compared to other sources. 
During January in the 3 habitats considered, these values were close to the mean $\delta^{13} \mathrm{C}$ vs. $\delta^{15} \mathrm{~N}$ of the stranded macroalgae Enteromorpha sp. and Fucus spiralis (Fig. 3). In addition, these results indicate that the dominant food sources within the marshes of Spartina maritima and Juncus maritimus were not used significantly by the locally occurring nematodes. Hence, in January the main assimilated food sources for these nematode communities were likely to originate from the

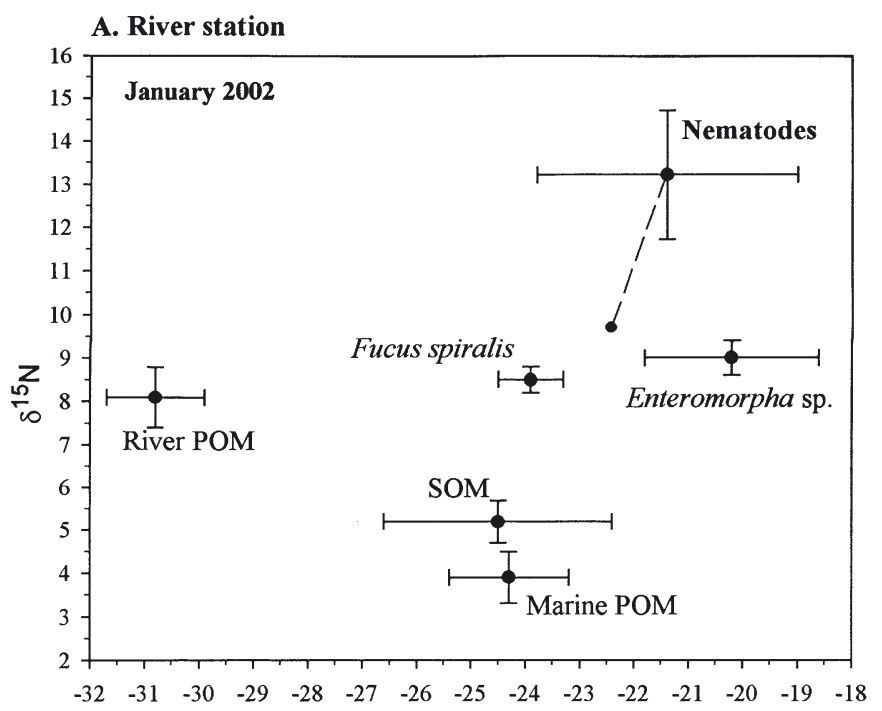

stranded macroalgae regularly deposited on the upper levels of the Aber Bay. During March, the theoretical diet of nematodes from the Spartina marsh suggested a mixed diet of stranded F. spiralis and Enteromorpha sp., while the diet of nematodes from the Juncus marsh was closer to stranded F. spiralis (Fig. 3B). Similarly, in March the theoretical diet of nematodes from the river station was closer to the stranded $F$. spiralis than to the river and marine POM (Fig. 3A). During this period, the absence of Enteromorpha sp.'s contribution to the nematode's diet may be because Enteromorpha sp. was only recently deposited at the sediment surface (Riera pers. obs.). This result is supported by the higher $\delta^{13} \mathrm{C}$ measured for stranded Enteromorpha sp. (i.e. $-11.0 \pm$ $0.7)$ in March, which is close to the $\delta^{13} \mathrm{C}$ values of -14.6 and $-10.2 \%$ reported for living Enteromorpha sp. inhabting the same area (Riera unpubl. data) and the Skagit Bay, USA (Hentschell 1998), respectively. This freshly deposited algae may have been poorly utilisable by nematodes because it was still in the early stages of decomposition.

During August at the river station, the isotopic values indicate a primary contribution of benthic diatoms to the diet of nematodes (Fig. 3A). This suggests that, when present at the sediment surface as brown mats, benthic diatoms are likely to be preferentially used by

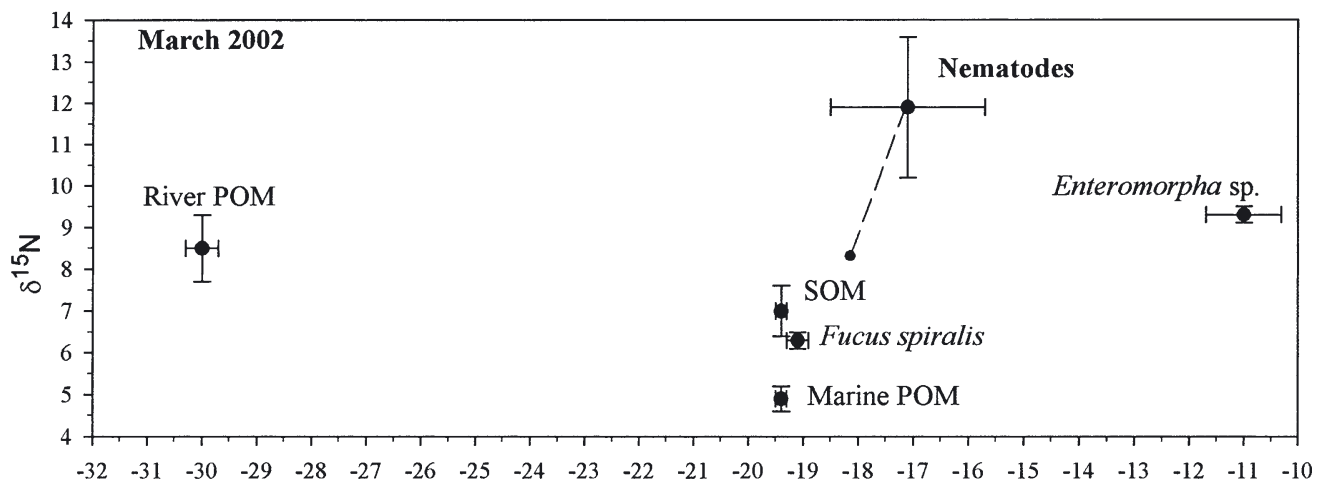

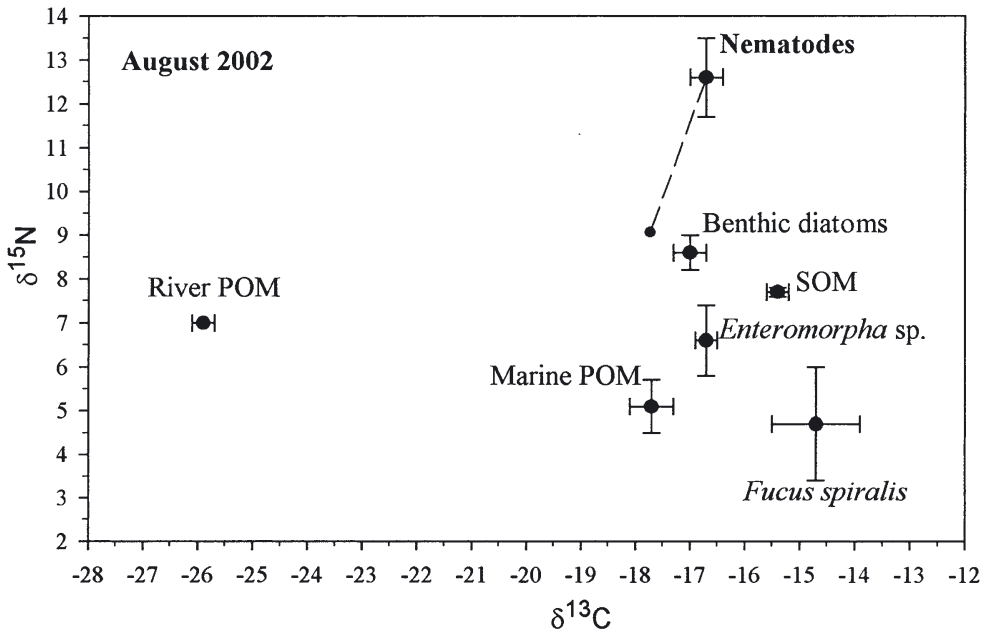

Fig. 3. $\delta^{13} \mathrm{C}$ vs. $\delta^{15} \mathrm{~N}$ (mean $\pm \mathrm{SD}$ ) for organic matter sources and nematodes during January, March and August 2002 at (A) the river station and (B) the Spartina maritima and Juncus maritimus marshes. 'Nematodes (Spartina)' and 'Nematodes (Juncus)' correspond to the nematode communities occurring in the $S$. maritima and $J$. maritimus marshes, respectively. (•) Average $\delta^{13} \mathrm{C}$ and $\delta^{15} \mathrm{~N}$ values corresponding to the theoretical food source of nematodes, taking into account trophic enrichment of 1 and $3.4 \%$ for $\delta^{13} \mathrm{C}$ and $\delta^{15} \mathrm{~N}$, respectively. (- -) Trophic enrichment of carbon and nitrogen. SOM: sedimented organic matter; POM: particulate organic matter 
nematodes over less readily utilisable sources (i.e. marine plants, macroalgae) as previously observed (Montagna et al. 1995, Riera et al. 1996). However, in

B. Spartina/Juncus marshes
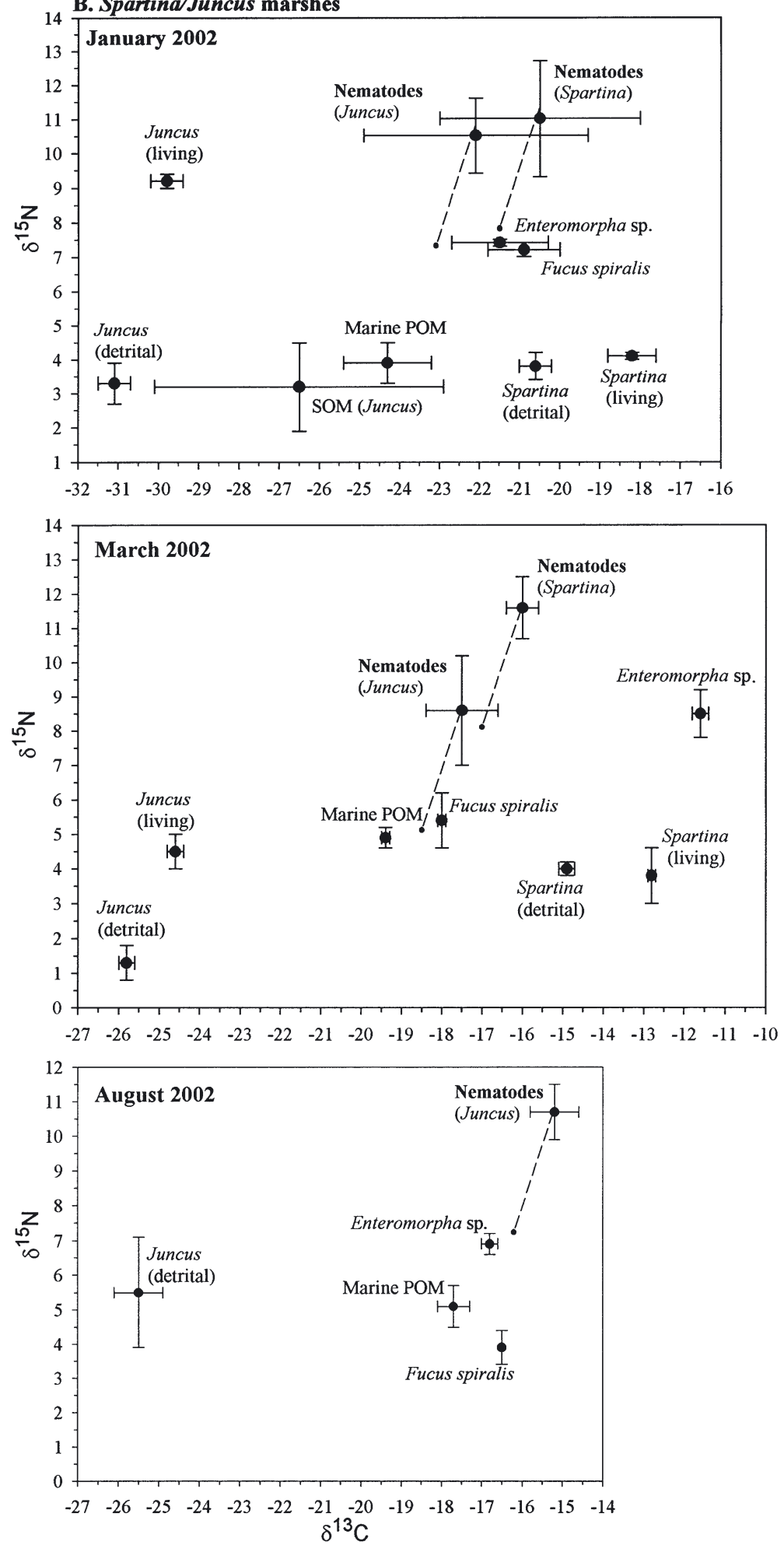

Fig. 3 (continued) the sampling areas considered, benthic diatoms occurred only as algal mats during summer, and could then be extracted for stable isotope analyses. This may be due to local hydrodynamic conditions and/or the fact that the sediment surface was often covered by a thin layer of decaying algae limiting its exposure to illumination (Riera pers. obs.).

Throughout the 3 sampling periods, the $\delta^{13} \mathrm{C}$ and $\delta^{15} \mathrm{~N}$ values of nematodes inhabiting the sediment from the river station clearly indicate that neither terrigeneous inputs carried by the river nor marine POM contributed a significant part of their assimilated food sources. In addition, these results show that, although the organic matter derived from Spartina maritima and Juncus maritimus largely dominated within the corresponding marshes, these sources did not contribute a significant part to the diet of local nematode communities. The $\delta^{13} \mathrm{C}$ and $\delta^{15} \mathrm{~N}$ values indicate that $S$. maritima and $J$. maritimus were too ${ }^{13} \mathrm{C}$-enriched and too ${ }^{13} \mathrm{C}$-depleted, respectively, to represent a primary food source for the corresponding nematode communities, either directly or through trophic mediation. Moreover, a significant diet contribution of these 2 plants to nematodes would lead to higher $\delta^{13} \mathrm{C}$ nematode differences, reflecting the mean $\delta^{13} \mathrm{C}$ difference between $S$. maritima and $J$. maritimus (i.e. from ca. 10 to $12 \%$ ), which is in contrast with our observations.

In addition, the significant temporal $\delta^{13} \mathrm{C}$ variation observed for nematodes at each sampling station is likely to be derived directly from the temporal $\delta^{13} \mathrm{C}$ variation observed in their preferred food sources (Table 1, Fig. 3). The absence of temporal $\delta^{15} \mathrm{~N}$ variation in these nematode communities, however, can reflect (1) the absence of temporal $\delta^{15} \mathrm{~N}$ variation in their food sources (Table 1), and (2) the temporal stability of their mean trophic level in this environment.

\section{Stranded macroalgae as a primary food source for nematodes}

To our knowneldge, there is no previous evidence of a primary contribution of stranded macroalgae to the assimilated food of intertidal nematodes. When considering that nematodes dominated in the meiofauna of the 3 microhabitats investigated (Fig. 2), and considering the intermediate trophic position of meiofauna, the food web of this area appears to be largely 
based on the use of stranded macroalgae by feeding nematodes. This functional role of stranded macroalgae is supported by regular field observations that, in the upper levels of the Aber Bay, stranded macroalgae from nearby rocks are regularly deposited by currents and waves (Riera pers. obs.). Although stranded macroalgae may be locally less abundant than autochthonous food sources, they are regularly available in this bay. In addition, terrigeneous inputs and marine plant detritus are not as readily utilisable for primary consumers as macroalgae, which contain relatively high amounts of nitrogen and can be readily assimilated by benthic consumers (Findlay \& Tenore 1982, Tenore 1983).

The availability of organic matter derived from macrophytes for primary consumers can depend on trophic mediation. This mediation may occur through associated bacteria (Langdon \& Newell 1990), but also through protozoa such as ciliates, which can ingest detrital particles (Posch \& Arndt 1996). $\delta^{15} \mathrm{~N}$ can be used to identify a trophic mediation within aquatic ecosystems, because an increase in $\delta^{15} \mathrm{~N}$ by ca. $3.4 \%$ per trophic level occurs as nitrogen is transferred (Wada et al. 1987, Post 2002). The present study provides evidence that microbial conversion is not necessary for assimilation of detritus derived from stranded macroalgae by nematodes, as opposed to the consumption of marine plants by marine invertebrates. However, high standard deviations of mean $\delta^{13} \mathrm{C}$ values for nematodes were observed on several sampling occasions (Fig. 3). This variability is consistent with (1) the variability of food sources for nematodes, including mostly decaying Enteromorpha sp. and Fucus spiralis and specific components of the SOM pool, and (2) the diversity of feeding guilds within the community, corresponding to different trophic levels (Weiser 1953, Moens \& Vincx 1997). It is therefore possible that variable isotope values reflected indirect routes of feeding, such as predation on protozoa, bacteria, or other co-occurring specimens of meiofauna (Gerlach 1977, Montagna \& Bauer 1988). Thus, high standard deviations associated with mean isotopic ratios may also reveal the functional complexity within a nematode community.

In conclusion, nematodes may preferentially use allochthonous stranded macroalgae as a food source, because the dominant sources of primary producers (i.e. marine phanerogams) are not as readily utilisable, and/or because benthic microalgae do not represent a primary food source. Finally, in future research, when stable isotope measurements and taxonomic identification can be simultaneously performed, a better understanding of resource partitioning for nematodes should preferably combine isotopic ratios of both the whole community and its most representative genera or species, as recently proposed by Moens et al. (2002).
Consistent with these authors, future research should also focus on dominant nematode populations, or the so-called bacteriophages, epistrate-feeders, non-selective deposit-feeders and omnivores-carnivores.

Acknowledgements. We would like to thank 4 anonymous reviewers for their comments which greatly contributed to the improvement of this manuscript.

\section{LITERATURE CITED}

Adin R, Riera P (2003) Preferential food source utilisation among stranded macroalgae by Talitrus saltator (Amphipod, Talitridae): a stable isotopes study in the northern coast of Brittany (France). Estuar Coast Shelf Sci 56:91-98

Benner R, Fogel ML, Sprague EK, Hodson RE (1987) Depletion of ${ }^{13} \mathrm{C}$ in lignin and its implications for stable carbon isotope studies. Nature 329:708-710

Blanchard G (1990) Overlapping microscale dispersion patterns of meiofauna and microphytobenthos. Mar Ecol Prog Ser 68:101-111

Bongers T, Ferris H (1999) Nematode community structure as a bioindicator in environmental monitoring. Trends Ecol Evol 14:224-228

Branch GM, Griffiths CL (1988) The Benguela ecosystem, Part V. The coastal zone. Oceanogr Mar Biol Annu Rev 26: 395-486

Carman KR, Fry B (2002) Small-sample methods for $\delta^{13} \mathrm{C}$ and $\delta^{15} \mathrm{~N}$ analysis of the diets of marsh meiofaunal species using natural-abundance and tracer-addition isotope techniques. Mar Ecol Prog Ser 240:85-92

Chauris L (1988) L'anse de l'Aber en Roscoff, un ancien marais littoral envahi par la mer. Penn Ar Bed 128:1-10

Colijn F, de Jonge VN (1984) Primary production of microphytobenthos in the Ems-Dollard Estuary. Mar Ecol Prog Ser 14:185-196

Couch CA (1988) A procedure for extracting large numbers of debris-free, living nematodes from muddy marine sediments. Trans Am Microsc Soc 107:96-100

Couch CA (1989) Carbon and nitrogen stable isotopes of meiobenthos and their food resources. Estuar Coast Shelf Sci 28:433-441

Coull BC, Bell SS (1979) Perspectives in meiofaunal ecology. In: Livingston RJ (ed) Ecological processes in coastal and marine systems. Plenum Press, New York, p 189-216

Currin CA, Newell SY, Paerl HW (1995) The role of standing dead Spartina alterniflora and benthic microalgae in salt marsh food webs: considerations based on multiple stable isotope analysis. Mar Ecol Prog Ser 121:99-116

DeNiro MJ, Epstein S (1978) Influence of diet on the distribution of carbon isotopes in animals. Geochim Cosmochim Acta 42:495-506

DeNiro MJ, Epstein S (1981) Influence of diet on the distribution of nitrogen isotopes in animals. Geochim Cosmochim Acta 45:341-351

Findlay S, Tenore K (1982) Nitrogen source for a detritivore: detritus substrate versus associated microbes. Science 218:371-373

Fry B, Sherr EB (1984) $\delta^{13} \mathrm{C}$ measurements as indicators of carbon flow in marine and freshwater ecosystems. Contrib Mar Sci 27:13-47

Gerlach SA (1977) Attraction to decaying organisms as a possible cause for patchy distribution of nematodes in 
Bermuda beach. Ophelia 16:151-165

Gerlach SA (1978) Food-chain relationships in a subtidal silty sand marine sediments and the role of meiofauna in stimulating bacterial productivity. Oecologia 33:55-69

Griffiths CL, Stenton-Dozey JME, Koop K (1983) Kelp wrack and the flow of energy through a sandy beach ecosystem. In: McLachlan A, Erasmus T (eds) Sandy beaches as ecosystems. Proc 1st Int Symp Sandy Beaches. Junk, The Hague, p 547-556

Hentschell BT (1998) Intraspecific variation in $\delta^{13} \mathrm{C}$ indicate ontagenic diet changes in deposit-feeding polychaetes. Ecology 79:1357-1370

Langdon CJ, Newell RIE (1990) Utilization of detritus and bacteria as food sources by two bivalve suspensionfeeders, the oyster Crassostrea virginica and the mussel Geukensia demissa. Mar Ecol Prog Ser 58:299-310

Minagawa M, Wada E (1984) Stepwise enrichment of ${ }^{15} \mathrm{~N}$ along food chains: further evidence and the relation between $\delta^{15} \mathrm{~N}$ and animal age. Geochim Cosmochim Acta 48:1135-1140

Moens T, Vincx M (1997) Observations on the feeding ecology of estuarine nematodes. J Mar Biol Assoc UK 77: 211-227

Moens T, Luyten C, Middelburg JJ, Herman PMJ, Vincx M (2002) Tracing organic matter sources of estuarine tidal flat nematodes with stable carbon isotopes. Mar Ecol Prog Ser 234:127-137

Montagna PA (1995) Rates of metazoan meiofaunal microbivory: a review. Vie Milieu 45:1-19

Montagna PA, Bauer JE (1988) Partitioning radiolabeled thymidine uptake by bacteria and meiofauna using metabolic blocks and poisons in benthic feeding studies. Mar Biol 98:101-110

Montagna PA, Yoon WB (1991) The effect of freshwater inflow on meiofaunal consumption of sediment bacteria and microphytobenthos in San Antonio Bay, Texas, USA. Estuar Coast Shelf Sci 33:529-547

Montagna PA, Blanchard GF, Dinet A (1995) Effect of production and biomass of intertidal microphytobenthos on meiofaunal grazing rates. J Exp Mar Biol Ecol 185:149-165

Pomeroy LR (1980) Detritus and its role as a food resource. In: Barnes RSK, Mann KH (eds) Fundamentals of aquatic ecosystems. Blackwell Science, Oxford, p 84-102

Posch T, Arndt H (1996) Uptake of sub-micrometre- and

Editorial responsibility: Otto Kinne (Editor),

Oldendorf/Luhe, Germany micrometre-sized detrital particles by bacterivorous and omnivorous ciliates. Aquat Microb Ecol 10:45-53

Post DM (2002) Using stable isotopes to estimate trophic position: models, methods and assumptions. Ecology 83: 703-718

Rau GH, Mearns AJ, Young DR, Olson RJ, Schafer HA, Kaplan IR (1983) Animal ${ }^{13} \mathrm{C} /{ }^{12} \mathrm{C}$ correlates with trophic level in pelagic food webs. Ecology 64:1314-1318

Rice DL (1982) The detritus nitrogen problem. New observations and perspectives from organic geochemistry. Mar Ecol Prog Ser 9:153-162

Riera P, Richard P (1996) Isotopic determination of food sources of Crassostrea gigas along a trophic gradient in the estuarine bay of Marennes-Oléron. Estuar Coast Shelf Sci 42:347-360

Riera P, Richard P, Grémare A, Blanchard G (1996) Food source of intertidal nematodes in the Bay of MarennesOléron (France), as determined by dual isotope analysis. Mar Ecol Prog Ser 142:303-309

Riera P, Stal LJ, Nieuwenhuize J, Richard P, Blanchard G, Gentil F (1999) Determination of food sources for benthic invertebrates in a salt marsh (Aiguillon Bay, France) by carbon and nitrogen stable isotopes: importance of locally produced sources. Mar Ecol Prog Ser 187:301-307

Riera P, Stal LJ, Nieuwenhuize J (2000) Heavy $\delta^{15} \mathrm{~N}$ in intertidal benthic algae and invertebrates in the Scheldt estuary (The Netherlands): effect of river nitrogen inputs. Estuar Coast Shelf Sci 51:365-372

Rullier F (1959) Etude bionomique de l'Aber de Roscoff. Trav Stat Biol Roscoff 10:1-350

Tenore KR (1983) What controls the availability to animals of detritus derived from vascular plants: organic nitrogen, enrichment or caloric availability? Mar Ecol Prog Ser 10: 307-309

Wada E, Terazaki M, Kabaya Y, Nemoto T (1987) ${ }^{15} \mathrm{~N}$ and ${ }^{13} \mathrm{C}$ abundances in the Antarctic Ocean with emphasis on the biochemical structure of the food web. Deep-Sea Res 34: 829-841

Weiser W (1953) Die Beziehung zwischen Mundhöhlengestalt, Ernährungsweise und Vorkommen bei freilebenden marinen Nematoden. Ark Zool 4:439-484

Whites DS, Howes BL (1994) Nitrogen incorporation into decomposing litter of Spartina alterniflora. Limnol Oceanogr 39:133-140

Submitted: April 10, 2003; Accepted: July 1, 2003

Proofs received from author(s): September 15, 2003 